\title{
THE NEXUS BETWEEN THE FEAR OF FLOATING AND EXPENDITURE-SWITCHING EXTERNAL ADJUSTMENT MECHANISM: EMERGING EUROPEAN AND LATIN AMERICAN FLOATERS
}

The focus of this research is the identification of the fear of floating (FOF) problem as a vulnerable ground for employing the exchange rate (ER) as a shock absorber with consequent limitations for expenditure-switching external adjustment mechanism. This research aims to fill the literature gap stressing the connection between FOF and the functioning of expenditure-switching external adjustment mechanism, highlighting the nexus from the viewpoint of emerging European vs. Latin American floaters, as well as from individual emerging European floaters (the Czech Republic, Hungary, Poland, Romania) in the period 2000Q1-2017Q2 with standard and panel VAR analysis. FOF is identified as a stronger reaction of foreign exchange reserves and interest rate to nominal ER shocks, as well as higher variations of real ER explained with price shocks compared to nominal ER shocks. As a confirmation, in countries with expressed FOF current account shock is more transmitted to economic activities (expenditure-reducing external adjustment) rather than nominal ER changes (expenditure-switching mechanism). The results confirm the vulnerable position of European emerging floaters compared to Latin American floaters, bearing in mind the stronger FOF coinciding with the higher currency mismatch. Within the sample of European emerging floaters the most vulnerable position concerning the nexus was detected for Romania, while the most favorable position was found in the case of Poland.

Keywords: fear of floating, external adjustment, emerging European economies, emerging Latin American economies, currency mismatch

JEL Classifications: F30, F32, F33

DOI: 10.15611 aoe.2020.1.03

\section{INTRODUCTION}

After the currency crashes of the late 1990s and early 2000s, a growing number of emerging economies moved away from exchange rate (ER) rigidity and adopted a combination of flexible ER and inflation targeting (IT). Economies with a floating exchange rate regime (ERR), i.e. floaters, have the

\footnotetext{
* Department of European and International Economics and Business, University of Novi Sad, Serbia.
} 
advantage concerning more maneuver space for external adjustment, having at their disposal both expenditure-reducing and expenditure-switching mechanism. Conceptually, external adjustment to negative external shocks can take place through changes in aggregate expenditure (expenditure-reducing mechanism) or changes in its composition (expenditure-switching mechanism). Expenditure-reducing channel reflects the reduction in purchasing power leading to a compression of domestic demand and consequently of imports. Another mechanism, expenditure-switching responds to a change in international prices, increasing exports and shifting the composition of domestic consumption and investment away from foreign goods towards domestic goods (Lane, Milesi-Ferreti 2014; Carriere-Swallow, Magud, Yepez 2018).

Although theoretically the floaters should experience full monetary flexibility in combining expenditure-switching and expenditure-reducing adjustments (Friedman 1953), as well as financing in right circumstances, the reality is different. The core of the expenditure-switching mechanism is nominal and real ER depreciations as a way to improve competitiveness via higher import prices and lower export prices. If obstacles to free ER movements are present then expenditure-switching mechanism will not bring (expected) results in improving the current account position; but what if countries cannot perform the first step - to allow nominal exchange depreciations? The answer to this question is reflected in fear of floating (FOF) phenomenon (Calvo, Reinhart 2002), most commonly associated with emerging economies. The de jure emerging floaters de facto significantly limit nominal ER depreciations directly via foreign exchange reserves and indirectly via the interest rate, mainly due to fear of inflation, unofficial 'dollarization/euroization' and contractionary depreciations. Emerging economies generally cannot perform the same type of floating regime as developed economies. Due to inherent vulnerabilities, these economies mostly practice a managed floating ER regime or "dirty" floating (Josifidis et al. 2014). Obviously, the question is to what extent emerging regions in general, and countries in particular, experience FOF, and in what way they limit excessive nominal ER fluctuations and accordingly the expenditureswitching mechanism, thus violating the role of ER as a shock absorber.

The focus of this research is the identification of the FOF problem and consequently the limitations for the expenditure-switching external adjustment mechanism in which ER serves as a shock absorber. The author is primarily interested in emerging European floaters, since emerging European economies generally experienced the highest external vulnerabilities in the pre-great recession period and the sharpest external adjustment in the post- 
great recession period. The nexus between FOF and expenditure-switching external adjustment is first analyzed via a comparison between emerging European and Latin American floaters, followed with a comparison within the European emerging floaters sample (the Czech Republic, Hungary, Poland and Romania). FOF is identified as a stronger reaction of foreign exchange reserves and interest rate to nominal ER shocks, as well as higher variations of real ER explained by price shocks compared to NER shocks (Edwards, Savastano 1999; Hausmann, Panizza, Stein 1999; Calvo, Reinhart 2002). In such circumstances, the role of $E R$ as a shock absorber, as the main advantage of floating ERRs, is necessarily narrowed down. As confirmation, in countries with expressed FOF current account shock is more transmitted to economic activities (expenditure-reducing external adjustment) rather than NER changes (expenditure-switching mechanism).

Extensive literature could be related with the FOF phenomenon and with external adjustment mechanisms in developed and emerging economies. However, this research aimed to fill the literature gap stressing the connection between FOF and the functioning of the expenditure-switching external adjustment mechanism, highlighting the nexus from the viewpoint of emerging European vs. Latin American floaters, as well as from the angle of individual emerging European floaters in the period 2000Q1-2017Q2 with standard and panel VAR analysis. The paper is structured as follows: Section 2 covers literature review, Section 3 - descriptive analysis, Section $4-$ methodological issues, Section 5 - a discussion of the results, and finally Section 6 concludes the paper.

\section{LITERATURE REVIEW}

Most countries experienced output and export contraction to a greater or lesser extent with the outbreak of the Great Recession. However, Latin American emerging economies (LAEEs) were a clear exception since the Global South, instead of following the Global North into a deep recession and financial crisis, has kept relatively robust levels of economic growth. The robust economic position of LAEEs could be attributed to the lowest levels of external debt in the world during several years preceding the crisis, the deleveraging process at an extraordinary fast pace, decreased dollarization and a current account surplus (Reinhart 2013). Investigating unprecedented resilience of Latin American economies to the global crisis, Gregorio (2013) stresses the role of sound macroeconomic conditions which allowed an unusual monetary and fiscal expansion, exchange rate flexibility, 
a strong and well-regulated financial system, high level of reserves, and very high terms of trade. The 'Achilles heel' of practicing flexible ERR in emerging economies has been the currency mismatching problem. Currency mismatch was more pronounced in emerging European economies, while it tends to decline in Latin American and South-Eastern Asian emerging countries. Lane and Milesi-Ferreti (2014) also underline the improved external position of Latin American economies bearing in mind positive change in the net position of foreign currency, the decline in external debt, the increase in FDI/portfolio equity on the liability side (tied to domestic currency reflecting dollarization weakening), and the accumulation of reserves.

In contrast to the relatively favorable position of LAEEs, the relatively high, growing and fundamental pre-crisis external imbalance of emerging European economies (EEE) was evident before the Great Recession. EEEs generally (excluding Poland) entered the recession and experienced higher losses of growth than all other emerging economies and developed economies put together. The convergence process and macroeconomic overheating in the pre-crisis period brought higher sensitivity to sudden stop episodes. Large foreign capital surges (also known as capital flow bonanzas) are to a large extent a natural part of the catching-up process with the euro area. However, despite the contribution to the rapid real convergence, foreign capital inflows also led to the build-up of imbalances and vulnerabilities (Vamvakidis 2008). Current account worsening reflected the unsustainable economic boom with an increasing output gap underpinned by the credit boom. A positive output gap tends to increase just before the Great Recession as a sign of unsustainable economic boom (Allegret, Sallenave 2015; Janković 2019). However, the overheating of emerging European economies was mostly financed with foreign capital resulting in an unsustainable current account position in contrast to the self-financing of economic growth in other emerging countries resulting in a stable current account position (Rahman 2008; Shelburne 2008). As a consequence, painful internal devaluation was in most cases unavoidable, as a sign of expenditurereducing adjustment mechanism under crisis-driven external shocks (Kang, Shambaugh 2014).

In general, large current account imbalances and large reversals are far less prevalent under floating ERRs (Edwards, Levy-Yeyati 2003; Ghosh, Terrrones, Zettelmeyer 2008). Ghosh, Ostry and Quareshi (2014) found that macroeconomic and financial vulnerabilities are significantly greater under less flexible intermediate regimes (including hard pegs) compared to floats. 
While intermediate regimes are still most susceptible to crisis, hard pegs are more prone to growth collapses. The emerging peggers are more likely to experience financial vulnerabilities reflected in stronger domestic credit and house price growth, as well as increases in bank leverage, compared to the emerging floaters. The spillover effects of global financial shocks are magnified for the peggers compared to the floaters mainly due to constrained monetary policy autonomy and higher sensitivity of capital flows to changes in global conditions (Obstfeld, Ostry, Quareshi 2017). There is no such thing as an ERR that provides for reasonable stabilization regardless of the source of shock and the fiscal/monetary instrument mix. Corsetti, Kuester and Muller (2017) proved this fact by analyzing ERRs after the Great Recession from the perspective of a small open economy. While an ER peg can be beneficial in the circumstances when recession originates domestically, a float dominates in the face of foreign deflationary demand shocks.

The maintenance of ER peg in a crisis period is connected to sharper deflation and reduction of economic activities in order to induce RER depreciation and competitiveness improvement compared to the floaters (Hoffman 2008; Jochem 2013). Devereux and Yu (2016) concluded that in 'normal times' the difference between an ER peg and a flexible ER is quite small, but in a crisis, nominal ER adjustment can play a beneficial role substantially reducing the negative impact of capital reversals. Accordingly, the floaters took advantage of ER as a shock absorber, engaging NER depreciation and expenditure-switching adjustment mechanism under crisis impact (De Gregorio 2013). Ghosh, Qureshi and Tsangarides (2014) also found a significant and empirically robust relationship between ER flexibility and the speed of external adjustment. However, the results of Lane and Milesi-Ferreti (2012) indicate that real ER has not played a supportive role over the 2008-2012 period, and consequently expenditure-switching adjustment has not been an important source of external adjustment, with a major burden placed on expenditure-reducing adjustment in the post-crisis period.

Although the floaters officially have all the freedom to exploit the expenditure-switching adjustment mechanism via currency weakening, when de facto situation is often related to the FOF phenomenon. The problem of ER fluctuations in emerging economies is especially emphasized since sharp depreciations could induce a currency crisis. Central banks which target the inflation could not afford to neglect the ER movements, hence mitigating excessive fluctuations is a reality. There is also a danger that ER is de facto transformed into a nominal anchor (Mishkin 2004). 
The degree of ER flexibility is closely tied to countries' inflation experiences, i.e. low ER flexibility is linked to (hyper)inflation during a transition/development period (Bakker 2017). Therefore, fear of inflation is one of the causes of FOF in emerging economies. Stable nominal variables, namely stable and low inflation environment, lead to lower levels of ER pass-through and thus contribute to weakening the FOF phenomenon (Baqueiro, Leon, Torres 2003). Bearing in mind that most emerging economies have made lasting and decisive progress with achieving monetary stability, fear of inflation as a cause of FOF was gradually relaxed (Edwards 2007; Mishkin, Schmidt-Hebbel 2007).

Another reason for FOF, or constrained ER flexibility, is the unofficial financial euroization/dollarization of balance sheets. Countries in which a large share of private (or public) debt is denominated in foreign currency tend to be reluctant to let their currencies float, out of fear that depreciation could trigger contractionary balance sheet effects, with repercussions for the real economy and the financial system (Belhocine et al. 2016). There are three main costs associated with unofficial euroization/dollarization which the literature traditionally highlights as the reduced monetary policy autonomy, limited lender of last resort ability, and adverse currency mismatches which arise for unhedged borrowers when the domestic currency depreciates (Chitu 2012). Depreciations are costly because the country, in particular its financial sector, is exposed to a currency mismatch between its assets and its liabilities that is not effectively hedged (Ganapolsky 2003). It is a wellknown fact that most developing countries are unable to borrow in their national currency. In this "original sin" scenario, domestic currency weakening significantly increases the debt burden and further stimulates policymakers to keep the ER as stable as possible (Eicheengreen, Hausmann, Panizza 2007). From the aspect of external adjustment mechanism, FOF constrains expenditure-switching adjustment and consequently the role of ER as a shock absorber.

FOF further generates other economic threats such as loss of competitiveness in exports, fall in the level of foreign official reserves and, potentially, the outburst of a currency crisis. However, ER volatility rises and, accordingly, FOF becomes weaker as the period of floating lengthens. Ibarra (2007) confirms this for selected Latin American economies, namely Chile, Colombia and Mexico. Higher ER flexibility and FOF shrinking has been a gradual phenomenon rather than a discrete adjustment at the time of the adoption of the floating regime. Thus, monetary autonomy is rather limited in the early stages of floating. Monetary instruments are confined 
with ER management and accordingly expenditure-switching adjustment is more or less limited during a strong FOF phase.

Policy intervention to dampen ER fluctuations is not limited to purchases and sales of foreign exchange reserves. In many emerging economies monetary authorities set domestic interest rates in order to stabilize the ER. Calvo and Reinhart (2002) analyze the behavior of ER, foreign exchange reserves and interest rates in the case of free and managed floaters in comparison to the committed floaters in order to identify FOF phenomenon. By constructing an ER flexibility index, the authors found that the variability in international reserves and interest rates is high relative to ER variations suggesting that the authorities are attempting to stabilize the ER through both direct intervention in the foreign exchange market and open market operations. Variabilities of ER, interest rates and foreign exchange reserves are also analyzed in Ball and Reyes (2008), who tried to expand the findings of Calvo and Reinhart (2002) in order to distinguish between FOF, IT and ER targeting. Mishkin (2004) claims that mitigating ER fluctuations is related to interest rate policy (indirect influence to the ER), while ER manipulation is linked with foreign exchange reserves (direct influence to the ER). The same applies to a central bank influencing the ER, indirectly via interest rates and directly through foreign exchange interventions, as emphasized in Lahiri and Vegh (2001) and Hufner (2004).

\section{DESCRIPTIVE ANALYSIS}

The vulnerable position of emerging European economies was especially stressed during the crisis episode. Namely, the external position of emerging European economies was relatively unfavorable when compared to other emerging regions (Figure 1). While Asian emerging economies recorded a surplus before the global crisis, as did CIS region, emerging European economies were in the worst position since the current account deficit recorded an abrupt accumulation a few years before the crisis. Latin American emerging economies were in a better position compared to the European one, without the accumulation of a current account deficit.

The above figure provides general insights concerning the external position of selected emerging groups, neglecting the difference between the peggers and the floaters. If one takes a closer look into the most vulnerable group of emerging economies, the external position and adjustment of emerging European economies was unambiguously dependent on the applied 


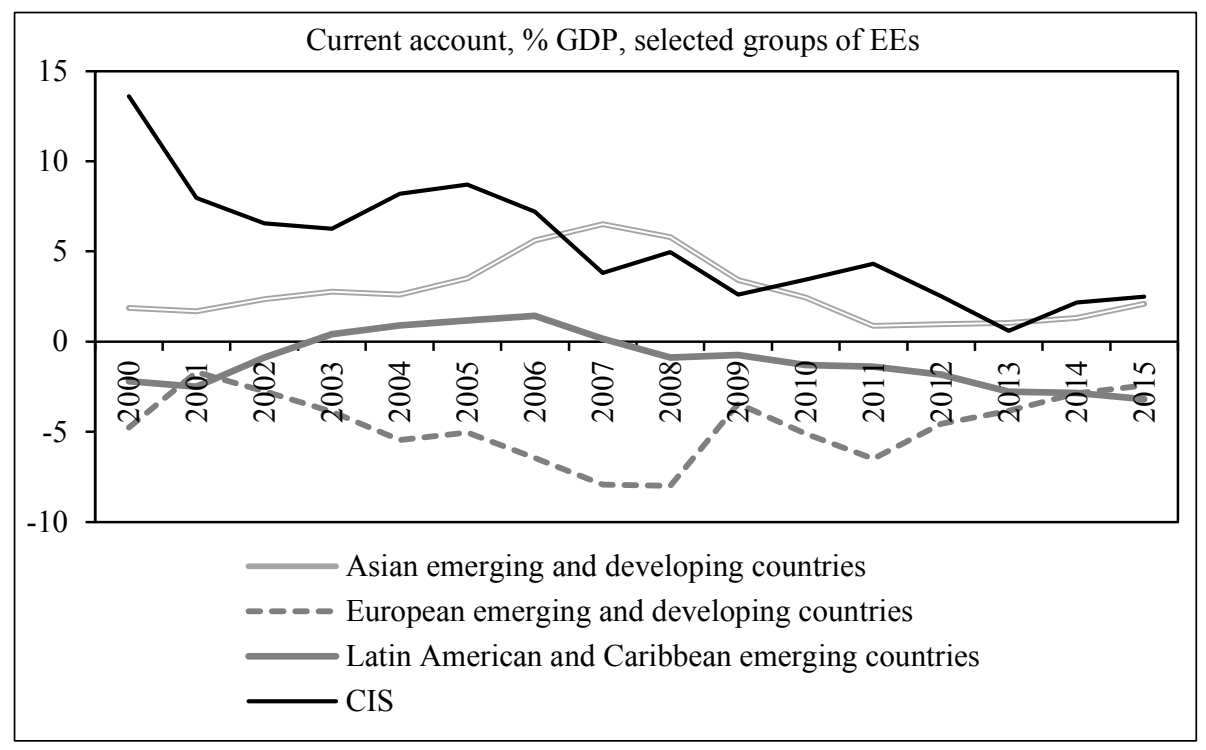

Fig. 1. External position of EEEs compared to other emerging regions

Source: author, according to International Financial Statistics yearly data.

ERR. Although the decision about the choice of ERR was motivated mainly by the desire to obtain exchange and monetary policy credibility and macroeconomic stability, it should be noted that the ERR choice is not just an economic issue. Political issues are also relevant in light of the further deepening European integration and joining the euro area. Slovenia in 2007 and Slovakia in 2009 switched towards the ERM II target zone in the preeuro phase. Although the peggers are not the focus of this paper, Estonia, Latvia and Lithuania in the post-crisis period also adopted the euro (in 2011, 2014 and 2015, respectively), but this de facto has not changed their nominal anchor and ERR even in the ERM II (Pietruscha 2015; Belhocine et al. 2016; Bakker 2017).

Figure 2 shows that the peggers were in a worse position concerning external imbalance accumulation in the pre-crisis period, as well as adjustment in the post-crisis period, compared to the floaters. If one bears in mind that the peggers cannot adopt expenditure-switching, but only expenditure-reducing mechanism, the negative consequence of the latter is a GDP drop, which is much stronger in the case of the peggers compared to the floaters (Figure 2). 


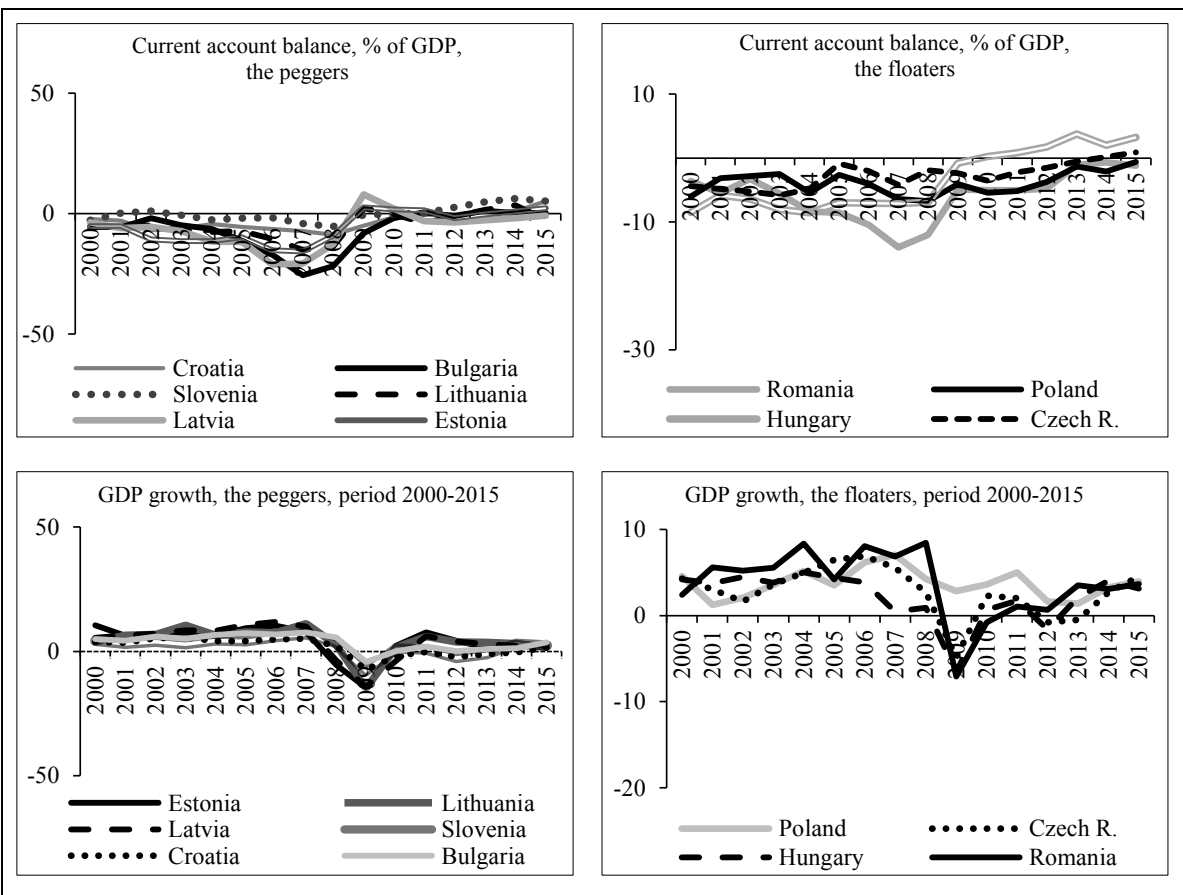

Fig. 2. Current account balance (\% of GDP) and GDP growth (in percent), 2000-2015, for European emerging peggers (left) and floaters (right)

Source: author, according to International Financial Statistics yearly data.

The floaters benefited from the role of ER as a shock absorber, hence currency depreciations are effective concerning automatic competitiveness improvement in all emerging regions (Gregorio 2013). Real ER variations are mostly initiated with nominal ER movements in the case of the floaters, while for the peggers real ER depreciations could be achieved via painful price adjustments as a response to restrictive economic policy (European Central Bank 2014). Figure 3 shows the nominal ER of selected emerging European floaters. A depreciation trend is evident in all cases in the postcrisis period indicating the use of expenditure-switching mechanism in order to perform external adjustment. The above Figure 2 indicates the functioning of an expenditure-reducing mechanism also in the case of the floaters (although in a much milder form compared to the peggers) suggesting the combination of both mechanisms of external adjustment (Lane, MilesiFerreti 2012). 


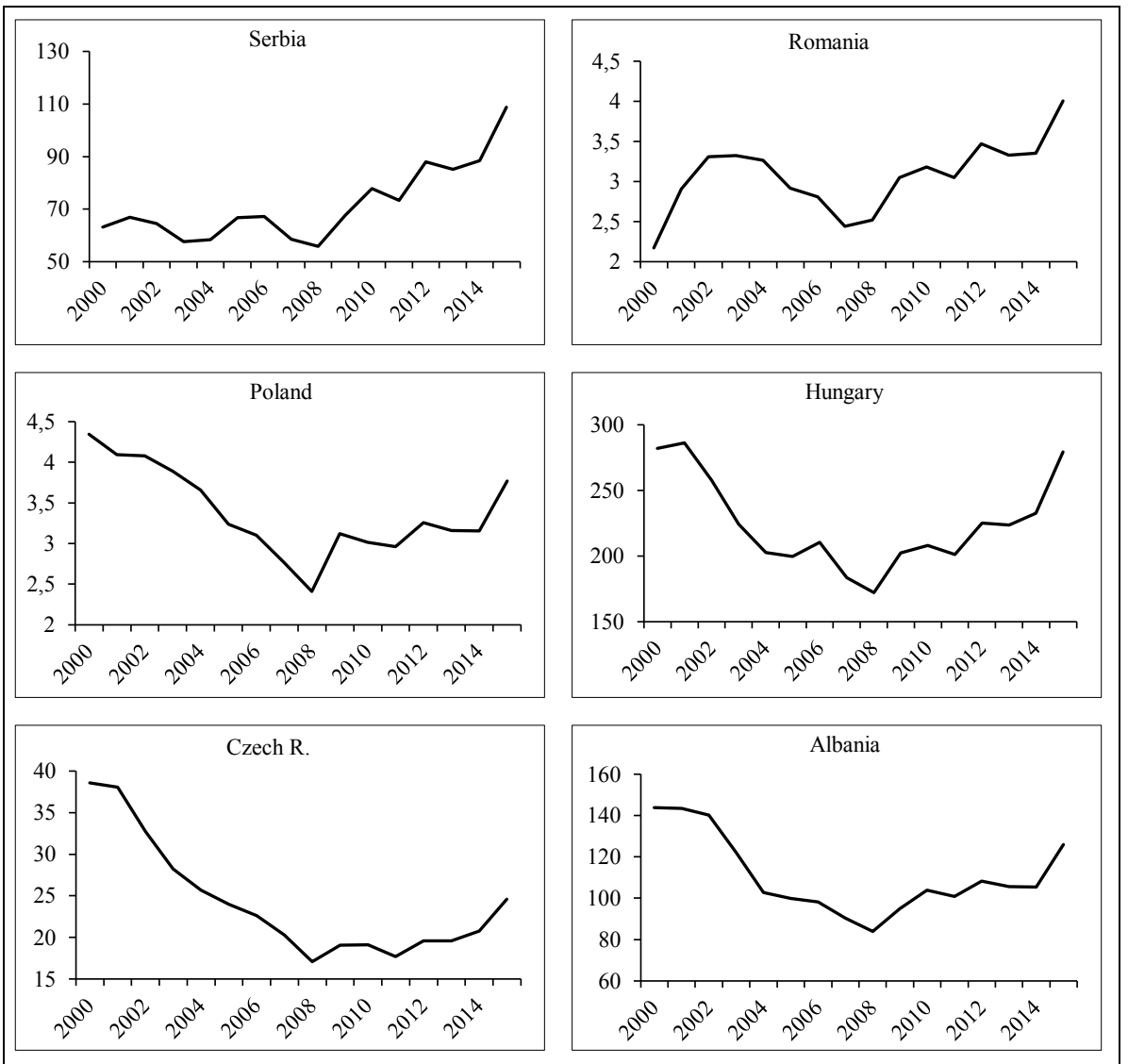

Fig. 3. Nominal ER of emerging European floaters, national currency per dollar

Source: author, according to the International Financial Statistics yearly data.

As mentioned in the previous section, one of the key reasons for the FOF problem is the currency mismatching problem. Currency mismatch arises when domestically oriented firms and households denominate their debt in foreign currency (for example, euros), while the cash flows that will service that debt are denominated in domestic currency. Since official, full or de jure euroization is one of the rigid ERRs (applied in Montenegro as EEE, for example), it should not be confused with unofficial, partial or de facto dollarization/euroization as a widespread phenomenon in emerging economies (Bofinger 2009). ER depreciations from the theoretical point of view should create an expansionary impact on the economy. Yet the depreciation 
impact can reverse in economies with a high liability dollarization/ euroization due to currency mismatches in the balance sheets of private agents. In this sense, large ER depreciations could include a contractionary or negative balance sheet effect, outpacing the desired expansionary effect. Moreover, the adverse impact of unofficial dollarization/euroization is found to be an amplifier of the Great Recession in emerging economies through the channels of currency mismatches, reduced monetary policy autonomy and limited lender of last resort ability (Chitu 2012). However, Uzun (2005) found that ER flexibility in the case of Latin American floaters and Turkey appears to reduce liability dollarization, i.e. the adoption of an IT regime and strengthening the institutional structure are significant in decreasing the level of financial dollarization.

The emerging economies' private and public sectors largely borrow in foreign currency and, consequently, the concept of liability dollarization/ euroization plays a crucial role in explaining FOF. The intensity of currency mismatching could be identified via indicators of foreign currency denominated loans and liabilities. Both indicators are more troubling for emerging European floaters (Figure 4).

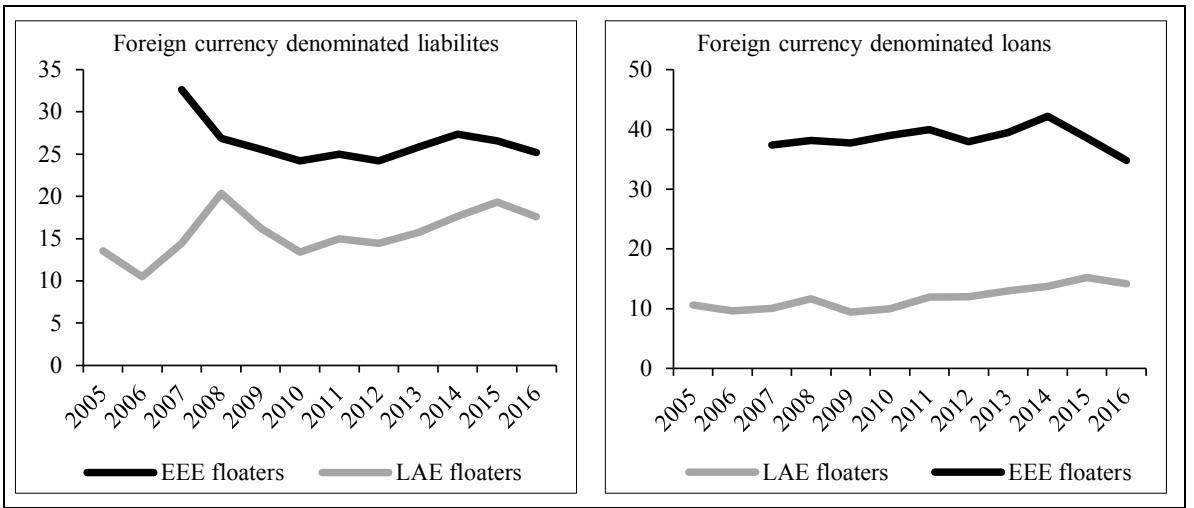

Fig. 4. Foreign currency denominated liabilities and loans (average, in percent) for emerging European and Latin American floaters

Source: author, according to the Financial Soundness Indicators, IMF, yearly data.

Currency mismatch is widespread in emerging Europe and it reached unprecedented levels in Eastern Europe before the recent crisis (Ranciere, Tornell, Vamvakidis 2010). Hence, more emphasized FOF and limited expenditure-switching mechanism could be expected in the case of emerging 
European floaters. Figure 5 differentiates between selected emerging European floaters, the Czech Republic, Poland and Romania, while Hungary is excluded from the figure only due to the missing data. Here one can see the more troubling position of Romania, while Poland and the Czech Republic experience lower currency mismatching. In the same manner, one can expect a more pronounced FOF, limited expenditure-switching external adjustment with more space for expenditure-reducing adjustment mechanism in the case of Romania.

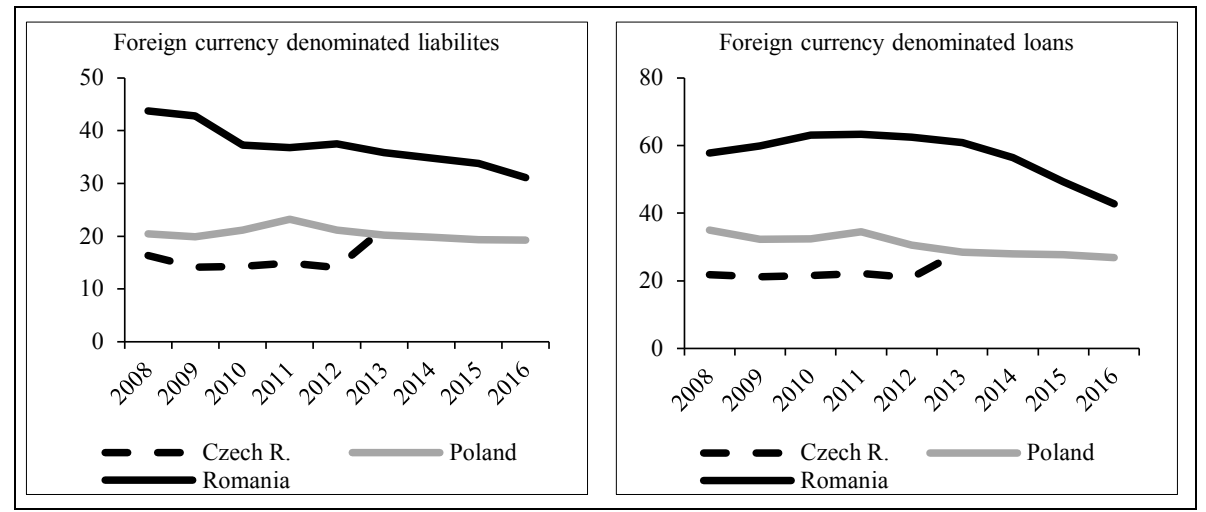

Fig. 5. Foreign currency denominated liabilities and loans (average, in percent) for the Czech Republic, Poland and Hungary

Source: author, according to the Financial Soundness Indicators, IMF, yearly data.

\section{METHODOLOGICAL FRAMEWORK}

\subsection{Transmission channels in identifying the FOF}

Real ER moves to facilitate adjustment to a current account imbalance, regardless of whether the ERR is fixed or flexible. Following a shock to external demand that creates current account deficit, the real ER will depreciate either through nominal ER depreciation or through a drop in domestic inflation, thus improving competitiveness, increasing exports and moderating imports. As already mentioned, floating ERs are superior to fixed ERs since following a real shock, the adjustment is reached by a movement of the nominal ER, which eliminates the need for a change in the price level. However, the proper change of real ER in the case of the peggers may occur only via the changes of relative prices that is connected 
with numerous costs such as GDP decrease and unemployment growth. The author try to detect which adjustment channel is dominant in real ER variations or which source of real ER variations prevails, nominal ER variations as a sign of expenditure-switching external adjustment, or price adjustments pointing to internal devaluation or expenditure-reducing external adjustment. The floaters with a relatively lower level of real ER variations explained with nominal ER shock, compared to price adjustments points to limited nominal ER variations, the constrained role of ER as a shock absorber and expenditure-switching external adjustment. This is a sign of the FOF phenomenon.

Other signs are related to the reaction of interest rates and reserves assets to a nominal ER shock. Interest rate is used as an indirect way to influence nominal ER (and a preferable way under an IT framework), while on the other hand, reserve assets serve as a direct way to limit fluctuations. If the FOF exists, monetary authorities will counteract or smooth out any large nominal ER movements using necessary instruments, i.e. through foreign exchange interventions or adjustments in reference interest rates. Higher reactions of both variables (foreign exchange reserves and interest rates) to nominal ER shock are signs of FOF. Variations of interest rates and foreign exchange reserves, as (in)direct way of managing the ER fluctuations, for the purpose of FOF detection are also used in Calvo and Reinhart (2002), Hufner (2003), Mishkin (2004), Ball and Reyes (2008), etc.

The next part of empirical research is based on the connection between previously identified FOF for selected emerging groups/countries and external adjustment mechanisms. Economies with less real ER variations explained with nominal ER and the stronger response of interest rates and reserve assets to nominal ER shock have a more emphasized FOF. The key assumption here is that a country group or a country with a more emphasized FOF does not fully employ ER as a shock absorber with a limited expenditure-switching external adjustment mechanism. This implies the stronger influence of current account shock to the real economy (variations of gross domestic product) and less transmission to nominal ER variations. On the other hand, economies with a less emphasized FOF are expected to benefit more from expenditure-switching adjustment under external shocks, with less output and employment losses as negative consequences of expenditure-reducing external adjustment. This beneficial case for the floaters generally appears when current account shock explains less variations of gross domestic product compared to the nominal ER 
variations. External adjustment channels, namely demand compression (expenditure-reducing) and expenditure-switching, as a connection between current account, output variables (gross domestic product) and exchange rates are also analyzed in Garcia-Solanes, Rodriguez Lopez and Torres (2007), Lane and Milesi-Ferreti (2014), Bussiere, Karadimitropoulou and Leon-Ledesma (2017).

\subsection{The model}

In trying to shed some light onto these aspects of the FOF phenomenon, the author employ the panel VAR model for the analysis of emerging European floaters (the Czech Republic, Hungary, Poland and Romania) vs. emerging Latin American floaters (Brazil, Chile, Colombia, and Mexico) ${ }^{1}$, while the standard VAR is used for the individual cases of the Czech Republic, Hungary, Poland and Romania, for the period 2000Q1-2017Q2. Sample countries are de jure floaters which implemented an IT monetary framework incompatible with ER targeting. Table 1 shows de facto applied ERRs in the combination with IT according to de facto classification of ER arrangements and monetary frameworks (Habermeier et al. 2009; International Monetary Fund 2017; Ilzetzki, Reinhart, Rogoff 2017). From the estimated (panel) VAR models, orthogonal impulse response functions (IRFs) and forecast error variance decompositions (FEVDs) are derived in order to track the transmission of: (i) nominal ER shock (impulse) to real ER, interest rates and reserve asset variations (responses), and (ii) current account shock (impulse) to gross domestic product and nominal ER variations (responses). All data are obtained from the IMF's International Financial Statistics database at quarterly frequency. ${ }^{2}$

\footnotetext{
${ }^{1}$ Serbia and Albania belong to the group of emerging European floaters, as well as Peru, Guatemala, Paraguay and Uruguay to the group of emerging Latin American floaters. However, these countries are excluded due to missing monthly/quarterly frequency data in the IMF (IFS) database.

2 International Financial Statistics database, International Monetary Fund, quarterly data, period 2000Q1-2017Q2: Gross domestic product - nominal, national currency. Current account - goods and services, net, US dollars. Nominal effective ER - trade partners by consumer price index. Real effective ER - based on consumer price index. Reserve assets official reserve assets, US dollars. Interest rate - for Latin American floaters - central bank policy rate, percent per annum for the Czech Republic, Poland, Romania - money market rate, percent per annum. For Hungary - discount interest rate, percent per annum.
} 
Table 1

De facto classification of ERRs and monetary frameworks applied in sample countries

\begin{tabular}{|c|c|c|c|c|c|c|c|}
\hline \multicolumn{4}{|c|}{ Emerging European Floaters } & \multicolumn{4}{|c|}{ Latin American Floaters } \\
\hline \multirow{2}{*}{ Countries } & \multicolumn{2}{|r|}{ ERR } & \multirow{2}{*}{$\begin{array}{l}\text { Monetary } \\
\text { framework }\end{array}$} & \multirow[b]{2}{*}{ Countries } & \multicolumn{2}{|r|}{ ERR } & \multirow{2}{*}{$\begin{array}{l}\text { Monetary } \\
\text { framework }\end{array}$} \\
\hline & $\operatorname{IMF}(2017)$ & \begin{tabular}{|l|} 
Ilzetzki, Reinhart, \\
Rogoff (2017) \\
\end{tabular} & & & \begin{tabular}{|c|} 
IMF \\
$(2017)$ \\
\end{tabular} & \begin{tabular}{|l|}
$\begin{array}{l}\text { Ilzetzki, Reinhart, } \\
\text { Rogoff (2017) }\end{array}$ \\
\end{tabular} & \\
\hline Poland & $\begin{array}{l}\text { Free } \\
\text { floating }\end{array}$ & \begin{tabular}{|l|} 
Managed floating until \\
2011, crawling band \\
since 2011 \\
\end{tabular} & $\begin{array}{l}\text { Inflation } \\
\text { targeting }\end{array}$ & Brazil & Floating & Managed floating & $\begin{array}{l}\text { Inflation } \\
\text { targeting }\end{array}$ \\
\hline Hungary & Floating & Crawling band & \begin{tabular}{|l|} 
Inflation \\
targeting
\end{tabular} & Chile & \begin{tabular}{|l|} 
Free \\
floating \\
\end{tabular} & Managed floating & \begin{tabular}{|l|}
$\begin{array}{l}\text { Inflation } \\
\text { targeting }\end{array}$ \\
\end{tabular} \\
\hline Czech R. & $\begin{array}{l}\begin{array}{l}\text { Stabilized } \\
\text { arrangement }\end{array} \\
\end{array}$ & Crawling band & \begin{tabular}{|l|} 
Inflation \\
targeting
\end{tabular} & Mexico & \begin{tabular}{|l|} 
Free \\
floating
\end{tabular} & Managed floating & $\begin{array}{l}\begin{array}{l}\text { Inflation } \\
\text { targeting }\end{array} \\
\end{array}$ \\
\hline Romania & Floating & $\begin{array}{l}\text { Managed floating until } \\
\text { 2006, crawling peg } \\
\text { until 2012, de facto peg } \\
\text { until } 2016\end{array}$ & $\begin{array}{l}\text { Inflation } \\
\text { targeting }\end{array}$ & Colombia & Floating & Managed floating & $\begin{array}{l}\text { Inflation } \\
\text { targeting }\end{array}$ \\
\hline
\end{tabular}

Source: Habermeier et al. (2009), International Monetary Fund (2017), Ilzetzki, Reinhart and Rogoff (2017).

The panel VAR model is estimated by fitting a multivariate panel regression of each dependent variable on lags of itself and lags of all other dependent variables. The fixed-effects estimator is not consistent in the dynamic panel because fixed effects are correlated with the regressors. According the procedure of Love and Zicchino (2006) and Love and Abrigo (2015), forward mean differencing or orthogonal deviation (the Helmert procedure) is applied. Namely, all variables in the model are transformed in deviations from forward means in order to remove the fixed effects. Roodman (2009) states that the first-difference procedure has the weakness of magnifying gaps in unbalanced panels, while the forward means differencing has the advantage of preserving sample size in unbalanced panels. If the original errors are not autocorrelated and are characterized by a constant variance (homoscedasticity), the transformed errors should exhibit similar properties (Arellano, Bover 1995). At the same time, the procedure allows the use of the lagged regressors as instruments and coefficient estimation by the Generalized Method of Moment (GMM) method. Panel VAR is estimated according to the procedures of Love and Zicchino (2006) and Love and Abrigo (2015).

Empirical steps preceding panel VAR estimation include the analysis of cross-section dependence (CSD), two generations of unit root tests, and selection of optimal lag length. Cross-section dependence (CSD) in macro panel data has received a lot of attention in the emerging panel time series 
literature over the past decade (Eberhardt 2009). Bearing in mind the relevance of cross-sectional (in)dependence in further analysis, the first step is to investigate variable and residual CSD in macro panels with the Pesaran CSD test in panel time series data (De Hoyos, Sarafidis 2006). For variables where the null hypothesis of cross-sectional independence is accepted, the first generation Maddala and $\mathrm{Wu}$ panel unit root test is applied, while in cases where the null has been rejected the second generation Pesaran panel unit root test is carried out (Pesaran 2003) ${ }^{3}$. Nominal effective ER (ner), gross domestic product (gdp) and reserve assets (res) are non-stationary as null hypothesis is accepted, while current account (ca), direct and portfolio investments (di, pi) are stationary series as null hypothesis is rejected ${ }^{4}$.

The empirical properties of the examined variables require the estimation of PVAR for stationary time series, i.e. PVAR includes first differences of log non-stationary variables, while log stationary variables enter the PVAR model in levels. For the purpose of choosing the optimal lag order ${ }^{5}$ in PVAR specification, Andrews and $\mathrm{Lu}$ (2001) proposed consistent moment and model selection criteria (MMSC) for GMM models based on Hansen's (1982) J statistic of over-identifying restrictions ${ }^{6}$. The stability condition of the estimated panel VAR is checked via the calculation of modulus of each eigenvalue of the estimated model. Stability is confirmed if all moduli of the companion matrix are strictly less than one ${ }^{7}$.

IRFs describe the reaction/response of an endogenous variable over time to the innovations/shock in another variable in the system, holding all other shocks at zero. Even though IRFs give information about the effect of changes in one variable on another, they do not show how important shocks

\footnotetext{
${ }^{3}$ Namely, the first generation panel unit-root tests are based on the assumption of crosssectional independence among panel units, which are mainly compared with economic theory and empirical results; while the second generation tests relax the assumption of crosssectional independence, allowing for a variety of dependence across the different panels.

${ }^{4}$ The results are available upon request.

${ }^{5}$ Furthermore, the correct lag length selection is essential for PVAR, having lags which are too short fails to capture the system's dynamics (omitted variable bias); having too many lags causes a loss of degrees of freedom (over-parameterization).

${ }^{6}$ Their proposed MMSC are analogous to commonly used maximum likelihood-based model selection criteria, namely the Akaike information criterion (AIC), the Bayesian information criterion (BIC), and the Hannan-Quinn information criterion (HQIC). The results are available from the authors upon request.

${ }^{7}$ If the PVAR is stable, over the short run shocks converge to zero, i.e. shocks are temporary, and over the long run the series return to their deterministic trends.
} 
on one variable are in explaining fluctuations in other variables. For this purpose, FEVDs measure the contributions of each source of shock to the (forecast error) variance of each endogenous variable at a given forecast horizon. In order to compute orthogonalized IRFs, the Cholesky decomposition (of the residual covariance matrix of the underlying panel VAR) is used, while IRFs confidence intervals are computed using 200 Monte Carlo simulations based on the estimated coefficients and their standard errors. Cholesky's IRFs and FEVDs show the response of the analyzed variables to a one standard deviation shock of the impulse in order to detect FOF phenomenon in selected emerging groups/economies. PVARs, compared to the standard VARs, by adding a cross sectional dimension, are a more powerful tool to address policy questions related to the transmission of shocks across borders. There are mainly two advantages in using the PVAR model: (i) it allows addressing the endogeneity problem and (ii) it overcomes the data limitation problem. The results provide insights which go beyond the estimated coefficients, reporting the adjustment and flexibility of observed variables to unexpected shocks (Bollano, Ibrahimaj 2015). For an overview of the PVAR models used in macroeconomics and finance, see Cannova and Ciccarelli (2013).

However, despite the already mentioned pros of panel VAR approaches, one cannot perform the comparison between individual emerging economies. Since the aim is to investigate vulnerable position of European floaters, the author check the above described relations for Poland, Czech Republic, Hungary and Romania. For each country, the usual empirical procedure for unrestricted VAR estimation has been applied. Stationarity of variables is analyzed via the Dickey-Fuller, Phillips-Perron and DF-GLS tests. In most cases the results of the unit root tests suggest the acceptance of the null hypothesis (non-stationarity), except for nominal effective ER in Romania and Poland, real effective ER in Poland, and interest rate in Romania. Other series enter the standard VAR model in first differences. According to the usual information criteria (AIC, HQIC, SBIC), adequate VAR order has been chosen. Since the estimated VAR models are stable, IRFs and FEVDs are derived to conclude nominal ER and current account shock transmission to different variables reflecting FOF and external adjustment mechanisms for the Polish, Czech, Romanian and Hungarian cases. 


\section{THE RESULTS DISCUSSION}

\subsection{The general impression: Emerging European floaters vs. Latin American floaters}

The IRFs (Figure 6) and FEVDs results (Table 2) indicate that the response of real ER to nominal ER shock is more intense in the case of Latin American economies compared to the European floaters. Nominal ER depreciation initiates real ER depreciations as a sign of automatic competitiveness improvement in an environment where ER plays a shock absorbing role. A year after the shock, about $80.8 \%$ of real ER variations in emerging European floaters could be explained with nominal ER shock, while the percent of real ER variations is higher for the Latin American

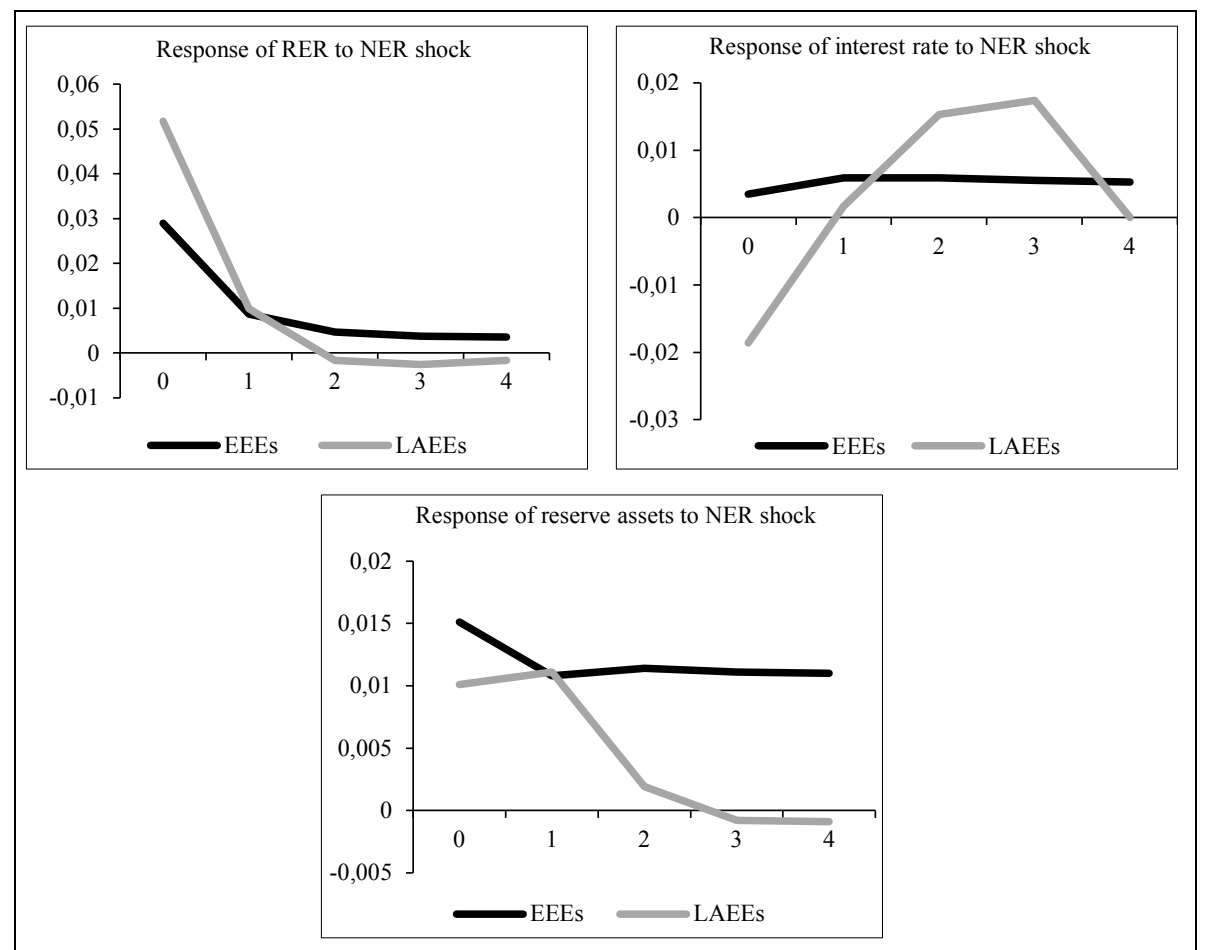

Fig. 6. IRFs - Responses of real ER (RER), interest rate and official reserves to nominal ER (NER) shock during four quarters for European (EEEs) and Latin American (LAEEs) emerging floaters

Source: author's research. 
floaters $(95.5 \%)$. The results suggest that although nominal ER does generally and dominantly transmit to real ER, bringing competitiveness adjustment, the transmission is more limited in the case of emerging European economies, i.e. with a higher ratio of price adjustments as a sign of expenditure-reducing adjustment mechanism.

Interest rates react weakly to nominal ER shock in the case of European floaters. Interest rate increased following nominal ER shock after the second up to the fourth quarter in the case of Latin American floaters. This indirect way of ER management is otherwise a more preferable way to limit excessive fluctuations under an IT framework. According to the results, European floaters almost do not use interest rate as a response to nominal ER shock. The $1 \%$ and $3.6 \%$ interest rate variations could be attributed to nominal ER shock after two years for emerging European and Latin American floaters respectively. This does not suggest significant ER management, although the manner of ER management is less favorable for European floaters, namely, concerning direct ER management via official reserve assets, the distinction is evident. In the case of European floaters, $14 \%$ of the reserves' variations could be explained with nominal ER shock, compared to the Latin American 7\% of variations. Both emerging groups record an increase (decrease) of foreign exchange reserves as a response to the appreciation (depreciation) trend of domestic currency, although this dynamic is more persistent for European floaters.

Table 2

FEVDs - Percent of real ER (RER), interest rate and official reserves variations explained by nominal ER (NER) shock

\begin{tabular}{c|c|c|c|c|c|c}
\hline \multirow{2}{*}{ Quarters } & \multicolumn{2}{|c|}{$\begin{array}{c}\text { Real ER response } \\
\text { to NER shock }\end{array}$} & \multicolumn{2}{c|}{$\begin{array}{c}\text { Interest rate response } \\
\text { to NER shock }\end{array}$} & \multicolumn{2}{c}{$\begin{array}{c}\text { Reserve assets response } \\
\text { to NER shock }\end{array}$} \\
\hline & EEEs & LAEs & EEEs & LAEs & EEEs & LAEs \\
\hline 1 & 80.31 & 98.61 & 0.06 & 1.64 & 3.56 & 3.32 \\
\hline 2 & 80.01 & 96.31 & 0.22 & 1.22 & 5.29 & 6.88 \\
\hline 3 & 80.13 & 95.64 & 0.39 & 1.85 & 7.13 & 6.97 \\
\hline 4 & 80.29 & 95.52 & 0.53 & 2.70 & 8.82 & 6.98 \\
\hline 5 & 80.44 & 95.49 & 0.66 & 3.25 & 10.33 & 7.00 \\
\hline 6 & 80.58 & 95.49 & 0.78 & 3.50 & 11.70 & 7.01 \\
\hline 7 & 80.71 & 95.49 & 0.89 & 3.59 & 12.93 & 7.01 \\
\hline 8 & 80.83 & $\mathbf{9 5 . 4 9}$ & 0.99 & $\mathbf{3 . 6 3}$ & $\mathbf{1 4 . 0 5}$ & 7.01 \\
\hline
\end{tabular}

Source: author's research. 
To sum up, previous results of nominal ER shock transmission to real $\mathrm{ER}$, interest rate and official reserves, suggest more limited expenditureswitching mechanism and more emphasized FOF in emerging European floaters due to: (i) higher ratio of price adjustments in real ER variations; and (ii) stronger reaction of foreign exchange reserves as a response to nominal ER shock. Therefore, the way of limiting nominal ER fluctuations in a FOF environment of emerging European economies is rather direct via official reserve assets variations, while Latin American floaters are more prone to use interest rate changes as a response to nominal ER shock.

The following results shed more light on the transmission of current account shock to domestic economic activities (as a way of identification of expenditure-reducing external adjustment) and nominal ER (as a way of identification of expenditure-switching external adjustment mechanism). IRFs (Figure 7) and FEVDs results (Table 3) indicate strong GDP destabilization following nominal ER shock in the case of emerging European floaters, while emerging Latin American floaters GDP almost do not react to current account shock. Economic activity decreases sharply in the first quarter in the case of European economies, although with relatively quick stabilization, presumably due to the combination with ER as a shock absorber. Regarding ER as a shock absorber role or expenditure-switching mechanism, nominal ERs appreciate (depreciate) in the case of current account improvement (deterioration) after current account shock for emerging European economies. Stronger external adjustment in emerging European

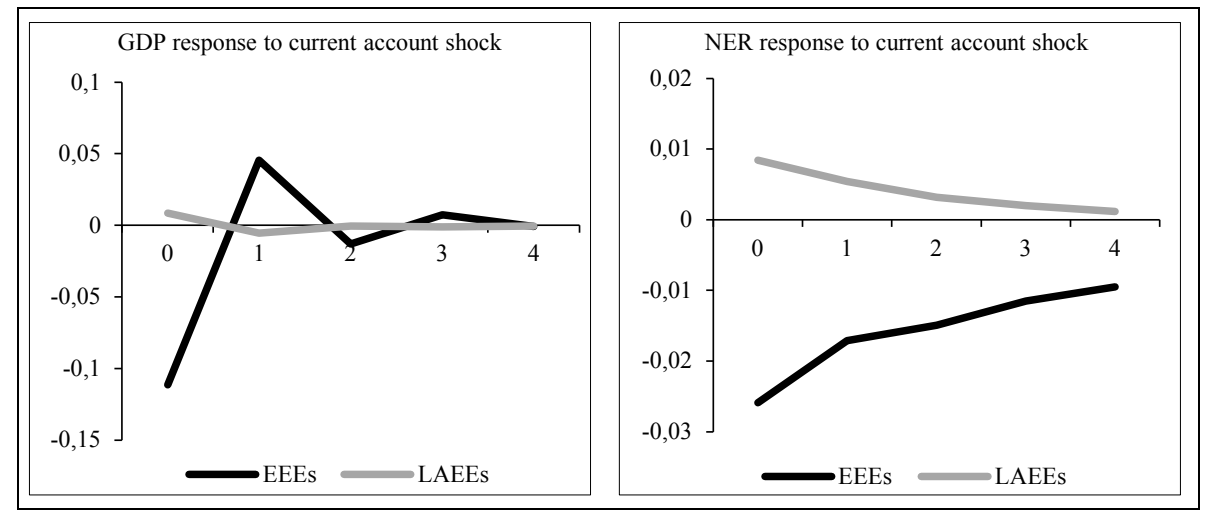

Fig. 7. IRFs - Responses of gross domestic product (GDP) and nominal ER (NER) to current account shock during four quarters for European (EEEs) and Latin American (LAEEs) emerging floaters

Source: author's research. 
economies is also confirmed with FEVDs results. Even $41.7 \%$ of GDP variations in emerging European floaters could be attributed to the current account shock, compared to $8.8 \%$ in the case of Latin American floaters. This confirms the dominance of expenditure-reducing adjustment mechanism for European floaters compared to Latin American floaters. Generally, both types of adjustment are stronger in emerging European economies which is expected bearing in mind worse external imbalance position and consequently sharper external adjustment. However, expenditure-reducing dominates over expenditure-switching adjustment implying more limited ER fluctuations and emphasized FOF phenomenon.

Table 3

FEVDs - Percent of nominal ER (NER) and gross domestic product (GDP) variations explained by current account (CA) shock

\begin{tabular}{c|c|c|c|c}
\hline Quarters & \multicolumn{2}{|c|}{ NER response to CA shock } & \multicolumn{2}{c}{ GDP response to CA shock } \\
\hline & EEEs & LAEs & EEEs & LAEs \\
\hline 1 & 36.82 & 2.64 & 45.42 & 6.79 \\
\hline 2 & 26.58 & 3.56 & 44.74 & 8.65 \\
\hline 3 & 21.36 & 3.91 & 44.12 & 8.64 \\
\hline 4 & 17.45 & 4.05 & 43.50 & 8.74 \\
\hline 5 & 14.65 & 4.10 & 43.00 & 8.76 \\
\hline 6 & 12.54 & 4.12 & 42.52 & 8.77 \\
\hline 7 & 10.95 & 4.13 & 42.11 & 8.77 \\
\hline 8 & $\mathbf{9 . 7 0}$ & 4.13 & $\mathbf{4 1 . 7 4}$ & 8.77 \\
\hline
\end{tabular}

Source: author's research.

To sum up, both types of external adjustment as a reaction to current account shock is significantly stronger for emerging European floaters, which is in accordance with their more deteriorated external position. ER as a buffer to external shocks works in combination with an expenditurereducing mechanism. Moreover, in the case of emerging European economies an expenditure-reducing mechanism is dominant with a stronger destabilization of output and high ratio of output variations in response to current account shock. Nominal ER variations dominantly translate into real ER variations in order to restore competitiveness, although part of real ER variations could be attributed to price adjustments as a sign of expenditurereducing mechanism. 


\subsection{Selected cases of emerging European floaters: the Czech Republic, Hungary, Poland and Romania}

Previous facts and findings indicate the sensitivity of emerging European economies regarding external position and adjustment. Now a more detailed analysis of selected emerging European floaters follows, which further investigates the same relations, this time with a standard VAR approach for the Czech Republic, Hungary, Poland and Romania. Since panel VAR generalizes conclusions, the following results reveal which emerging European economy is most sensitive and which is in a more favorable position concerning the nexus between FOF and expenditure-switching mechanism.

As a response to nominal ER shock, real ER reacts in the same expected way for all emerging European floaters, with the stabilization after the second quarter (Figure 8). Real ER variations and competitiveness improvement, as indicators of ER as a shock absorber, are the highest for Poland, followed by Hungary, the Czech Republic, and Romania with the lower nominal ER transmission. FEVDs results (Table 4) confirm the same. Almost $99 \%$ of real ER variations in Poland are attributed to nominal ER shock in the first quarter, followed by Hungary with 97\%, the Czech Republic with $90 \%$ and Romania with $88 \%$ of real ER variations. Usually, nominal ER variations improve competitiveness but in the case of the Czech Republic and Romania there are signs of price adjustments (the remaining real ER variations not explained with nominal ER shock).

Concerning the response of interest rate and official reserves to nominal ER shock, in order to detect which country and in what way (indirectly via interest rate or directly via reserve assets) they react to nominal ER shock in a need to limit the fluctuations, Romanian official reserves and interest rate mostly react to the shock. These findings are in accordance with Romanian highest currency mismatching problem and the previously lower nominal ER transmission to real ER variations. The dominant way to withstand excessive fluctuations in FOF environment is direct via foreign exchange reserves; $16.7 \%$ of reserve variations in the case of Romania are explained with the shock in the first quarter, compared to $6.6 \%$ for Poland, $4 \%$ for the Czech Republic and Hungary 3.8\% (Table 4). Hungary mostly uses the indirect way to influence the ER compared to other countries, since $10.2 \%$ of interest variations are due to nominal ER shock, followed by Poland with $9.2 \%$, the Czech Republic with 3.2\% and Romania with $2.5 \%$. The most emphasized FOF is found for Romania compared to other countries, with mainly direct limiting of ER via foreign exchange interventions. In the case of the Czech 
Republic the author identified the least response to nominal ER shock, while for Hungary and Poland an interest rate was used more as a preferable way to limit nominal ER fluctuations within an IT monetary framework.

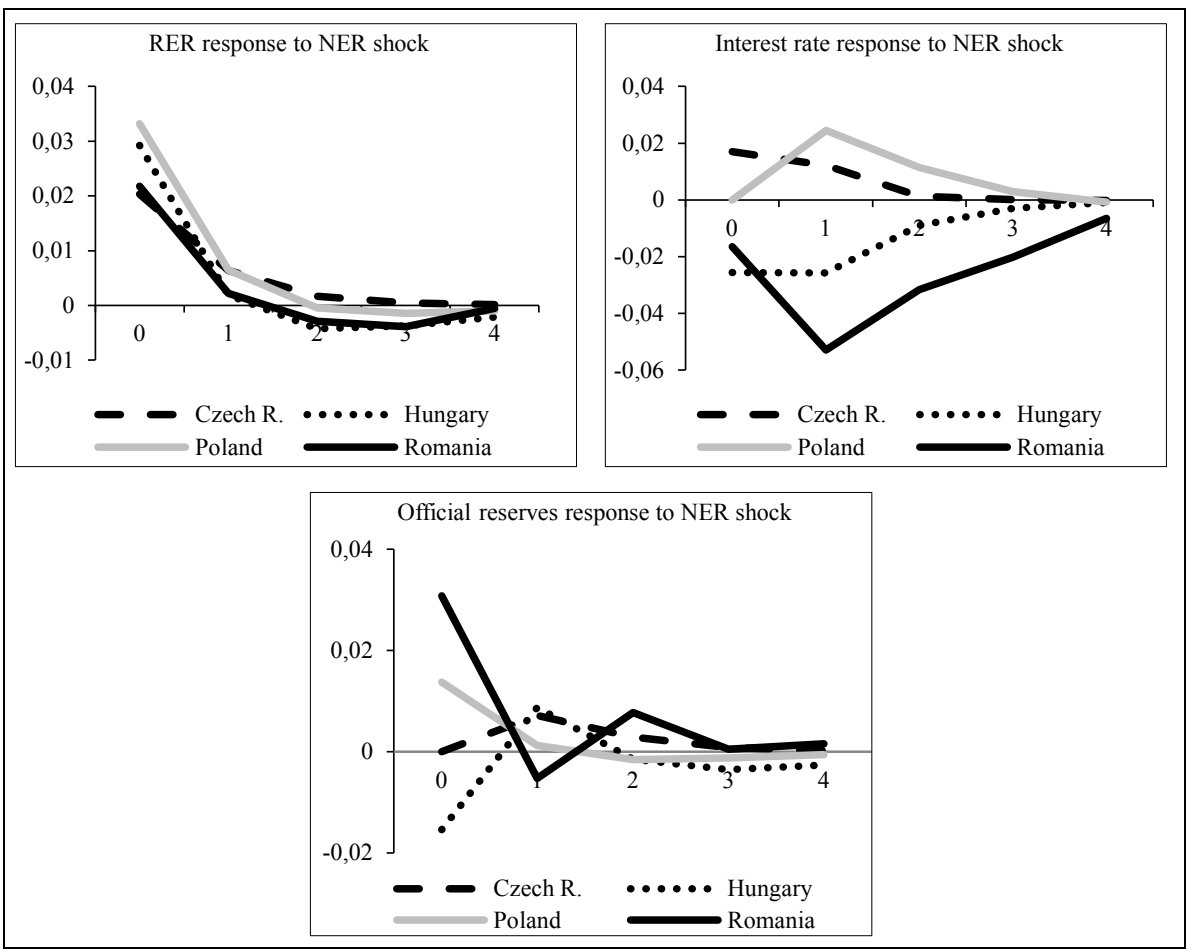

Fig. 8. IRFs - Responses of real ER (RER), interest rate and official reserves to nominal ER (NER) shock during four quarters in the case of the Czech Republic, Hungary, Poland and Romania

Source: author's research.

Under current account shock, the economic activity of Romania is the most destabilized since GDP sharply decreased following the shock and stabilized only after a year (Figure 9). While in the case of Romania the expenditure-reducing adjustment mechanism is dominant due to most emphasized FOF and consequently limited expenditure-switching, in other emerging European economies significant GDP response to current account shock is not evident. The Czech Republic mostly employs an expenditureswitching mechanism, followed by Poland, and Hungary with an almost 
Table 4

FEVDs - Percent of real ER (RER), interest rate and official reserves variations explained by nominal ER (NER) shock in the cases of the Czech Republic, Hungary, Poland and Romania

\begin{tabular}{|c|c|c|c|c|}
\hline \multirow{2}{*}{ Quarters } & \multicolumn{4}{|c|}{ RER response to NER shock } \\
\hline & Czech R. & Hungary & Poland & Romania \\
\hline 1 & 90.03 & 97.11 & 98.92 & 87.73 \\
\hline 2 & 85.76 & 86.45 & 76.02 & 84.35 \\
\hline 3 & 85.09 & 82.55 & 74.21 & 70.04 \\
\hline 4 & 84.93 & 81.62 & 73.91 & 70.14 \\
\hline 5 & 84.89 & 81.43 & 73.76 & 69.88 \\
\hline 6 & 84.88 & 81.4 & 73.70 & 69.49 \\
\hline 7 & 84.88 & 81.4 & 73.67 & 69.37 \\
\hline 8 & 84.88 & 81.4 & 73.67 & 69.28 \\
\hline \multirow{2}{*}{ Quarters } & \multicolumn{4}{|c|}{ Interest rate response to NER shock } \\
\hline & Czech R. & Hungary & Poland & Romania \\
\hline 1 & 2.71 & 5.34 & 4 & 0.72 \\
\hline 2 & 3.30 & 9.7 & 9.4 & 3.41 \\
\hline 3 & 3.19 & 10.16 & 9.5 & 3 \\
\hline 4 & 3.16 & 10.21 & 9.2 & 2.51 \\
\hline 5 & 3.16 & 10.21 & 9.08 & 2.08 \\
\hline 6 & 3.16 & 10.21 & 9.05 & 1.78 \\
\hline 7 & 3.16 & 10.21 & 9.04 & 1.58 \\
\hline 8 & 3.16 & 10.21 & 9.04 & 1.48 \\
\hline \multirow{2}{*}{ Quarters } & \multicolumn{4}{|c|}{ Official reserves response to NER shock } \\
\hline & Czech R. & Hungary & Poland & Romania \\
\hline 1 & 3.96 & 3.79 & 5.62 & 16.74 \\
\hline 2 & 4.65 & 4.76 & 5.43 & 17.02 \\
\hline 3 & 4.76 & 4.75 & 5.48 & 17.54 \\
\hline 4 & 4.77 & 4.91 & 5.52 & 17.46 \\
\hline 5 & 4.77 & 5 & 5.52 & 17.39 \\
\hline 6 & 4.77 & 5.04 & 5.52 & 17.32 \\
\hline 7 & 4.77 & 5.04 & 5.52 & 17.27 \\
\hline 8 & 4.77 & 5.04 & 5.52 & 17.23 \\
\hline
\end{tabular}

Source: author's research.

absent reaction of nominal ER to current account shock. The results of FEVDs (Table 5) reveal that expenditure-switching adjustment mechanism is mostly exploited in the case of the Czech Republic compared to other countries. However, GDP in the Czech Republic also mostly responds to current account shock indicating a strong expenditure-reducing mechanism, followed by Romanian GDP as the already mentioned vulnerable case. Generally, emerging European floaters adjust more via GDP as a consequence 


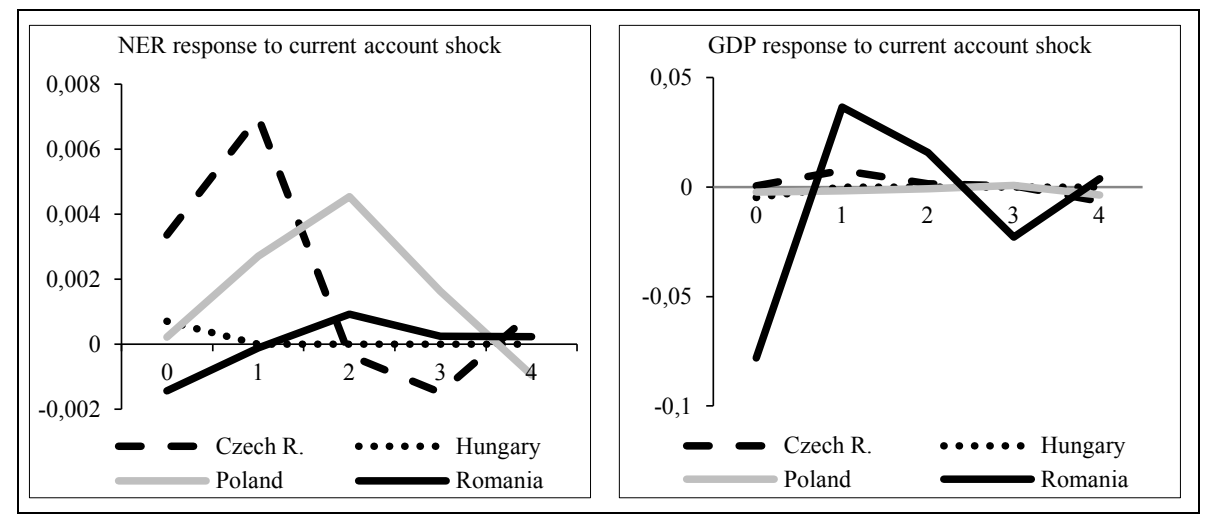

Fig. 9. IRFs - Responses of gross domestic product (GDP) and nominal ER (NER) to current account shock during four quarters for the Czech Republic, Hungary, Poland and Romania

Source: author's research.

Table 5

FEVDs - Percent of nominal ER (NER) and gross domestic product (GDP) variations explained by current account (CA) shock for the Czech Republic, Hungary, Poland and Romania

\begin{tabular}{c|c|c|c|c}
\hline \multirow{2}{*}{ Quarters } & \multicolumn{4}{|c}{ NER response to CA shock } \\
\cline { 2 - 5 } & Czech R. & Hungary & Poland & Romania \\
\hline 1 & 3.56 & 0.05 & 0 & 0.29 \\
\hline 2 & 13.46 & 0.05 & 0.55 & 0.12 \\
\hline 3 & 13.24 & 0.05 & 1.9 & 0.11 \\
\hline 4 & 13.09 & 0.05 & 2 & 0.09 \\
\hline 5 & 13.02 & 0.07 & 2.03 & 0.08 \\
\hline 6 & 13.05 & 0.07 & 2.24 & 0.07 \\
\hline 7 & 13.03 & 0.07 & 2.3 & 0.07 \\
\hline 8 & 13.63 & 0.07 & 2.34 & 0.07 \\
\hline \multirow{2}{*}{ Quarters } & & GDP response to CA shock & \\
\cline { 2 - 5 } & Czech R. & Hungary & Poland & Romania \\
\hline 1 & 0.18 & 3.12 & 2.68 & 18.86 \\
\hline 2 & 21.25 & 3.12 & 3.84 & 18.78 \\
\hline 3 & 20.11 & 3.12 & 2.94 & 17.59 \\
\hline 4 & 19.81 & 3.12 & 4.08 & 16.94 \\
\hline 5 & 22.50 & 7.31 & 5.67 & 16.93 \\
\hline 6 & 29.06 & 7.31 & 5.53 & 16.54 \\
\hline 7 & 28.27 & 7.31 & 5.38 & 16.54 \\
\hline 8 & 27.99 & 7.31 & 5.67 & 16.47 \\
\hline
\end{tabular}

Source: author's research. 
of expenditure-reducing mechanism, while to a lesser extent ER was used as a buffer to the external shock. Differences, however, exist since the Czech Republic reacts with both mechanisms, while Romania strongly reacts only with expenditure-reducing mechanism due to a stronger FOF problem.

\section{CONCLUDING REMARKS}

The paper highlights the nexus between the FOF problem and expenditure-switching adjustment mechanism from the angle of two emerging regions, Europe and Latin America. The results of standard and panel VAR model for the period 2000Q1-2017Q2 suggest a more pronounced FOF problem for emerging European floaters as a vulnerable ground for employing ER as a shock absorber with consequent limitations for expenditureswitching external adjustment mechanism.

The transmission of nominal ER shock to real ER variations as a sign of competitiveness improvement and better shock absorbing role is stronger for the Latin American floaters compared to the European ones. Both types of external adjustment, expenditure-reducing and expenditure-switching, are more pronounced for emerging European floaters, which is expected bearing in mind the more deteriorated European external position in the observed period. However, the expenditure-reducing mechanism is more dominant with larger destabilization of output as the higher ratio of output variations is explained with the current account shock. The FOF of emerging European economies is connected with the more emphasized currency mismatching problem, compared to the Latin American emerging floaters. The way of limiting nominal ER fluctuations in the FOF environment of emerging European economies is rather direct via official reserve assets, while Latin American floaters employ more the interest rate in response to nominal ER shock as a more acceptable way in an IT framework.

Concerning the explored nexus within the selected sample of emerging European floaters the Romanian position is the most sensitive. This conclusion is based on the relatively most emphasized currency mismatching problem, the strongest reaction of official reserves and interest rate to nominal ER shock, as well as the lower transmission of nominal ER shock to real ER variations as a framework for FOF and the suppressed role of ER as a buffer against external shocks. Accordingly, Romanian output is sharply destabilized as a reaction to current account shock as a sign of stronger expenditure-reducing external adjustment instead of expenditure-switching adjustment as a benefit of floating ERRs. On the other hand, the relatively 
weaker FOF problem, the stressed role of ER as a shock absorber, along with the advantage of the expenditure-switching external adjustment mechanism, are found in the cases of Poland, followed by Hungary and the Czech Republic.

The vulnerable position of emerging European floaters regarding the more emphasized FOF limits the shock absorbing role of ER, while the expenditure-switching external adjustment mechanism is constrained under external shocks. The nexus is a warning for the monetary authorities of emerging European floaters generally, especially for the Romanian authorities, to draw some lessons from the Latin American experience. The deleveraging process, lowering of external debt, foreign reserves accumulation, improvement of current account position, strong and well regulated financial system, and especially the constant efforts of lowering the currency mismatching problem, are the priorities that should weaken FOF and improve monetary performance under an IT framework.

\section{REFERENCES}

Allegret, J.-P., Sallenave, A., Capital flow bonanzas and monetary policy in emerging Europe: responses to the global financial crisis, "Post-Communist Economies", 27, pp. 429-447, 2015.

Andrews, D. W. K., Lu, B., Consistent model and moment selection procedures for GMM estimation with application to dynamic panel data models, "Journal of Econometrics", 101, pp. 123-164, 2001.

Arellano, M., Bover, O., Another look at the instrumental variable estimation of error components model, "Journal of Econometrics", 68, pp. 29-51, 1995.

Ball, C. P., Reyes, H., Inflation targeting or fear of floating in disguise? A broader perspective, "Journal of Macroeconomics", 30 (1), pp. 308-326, 2008.

Baqueiro, A., Díaz de León, A., Torres, A., Fear of floating or fear of inflation? The role of the exchange rate pass through, [In:] Monetary policy of a changing environment, vol. 19, Bank for International Settlements, pp. 338-354, 2003.

Belhocine, N., et al., Taking Stock of Monetary and Exchange Rate Regimes in Emerging Europe, IMF Departmental Paper Series, 2016.

Bollano, J., Ibrahimaj, D., Current account determinants in Central Eastern European countries, Graduate Institute Geneva Working Paper, no. HEIDWP0022-2015, Geneva 2015.

Bofinger, T., Monetary Policy under De Facto Dollarization: The Cases of Peru and Croatia, https://www.wiwi.uni-wuerzburg.de/fileadmin/12010100/Diplomarbeiten/Schaub-Diplomarbeit.pdf, 2009.

Bussiere, M., Karadimitropoulou, A., León-Ledesma, M. A., Current account and the real exchange rate: Disentangling the evidence, Bank of Greece Eurosystem Working Paper, no. 239, 2017. 
Calvo, G. A., Reinhart, C. M., Fear of floating, "The Quarterly Journal of Economics", CXVII (2), pp. 379-408, 2002.

Canova, F., Ciccarelli, M., Panel vector autoregressive models - a survey, ECB Working Paper, no. 1507, 2013.

Carrière-Swallow, Y., Magud, N. E., Yépez, J. F., No Pain, All Gain? Exchange Rate Flexibility and the Expenditure-Switching Effect, IMF Working Paper, no. 18/213, 2018.

Chitu, L., Was Unofficial Dollarization/Euroisation an Amplifier of the 'Great Recession' of 2007-09 in Emerging Economies? ECB Working Paper, no. 473, 2012.

Corsetti, G., Kuester, K., Müller, G. J., Fixed on flexible rethink exchange rate regimes after the Great Recession, CFM discussion paper series, no. 2017-21, 2017.

De Hoyos, R., Sarafidis, V., Testing for cross-sectional dependence in panel-data models, "Stata Journal", 6, pp. 482-496, 2006.

Devereux, M. B., Yu, C., ER adjustment in financial crisis, https://www.imf.org/external/ np/seminars/eng/2016/ExchangeRates/pdf/Devereux.pdf, 2016.

Eberhardt, M., Nonstationary panel econometrics and common factor models: An introductory reader, Unpublished mimeo, 2009.

Edwards, S., Savastano, M. A., Exchange Rates in Emerging Economies: What Do We Know? What Do We Need to Know? http://citeseerx.ist.psu.edu/viewdoc/download? doi=10.1.1.196.4254\&rep=rep1\&type=pdf, 1999.

Edwards, S., Levy Yeyati, E., Flexible Exchange Rates as Shock Absorbers, NBER Working Paper, no. 9867, 2003.

Edwards, S., The relationship between exchange rates and inflation targeting revisited, [in:] Mishkin, F., Schmidt-Hebbel, K. (eds.), Monetary Policy under Inflation Targeting, pp. 373-413. Central Bank of Chile, Santiago 2007.

Eichengreen, B., Hausmann, R., Panizza, U., Currency mismatches, debt intolerance, and original sin: Why they are not the same and why it matters, [in:] Edwards, S. (ed.), Capital controls and capital flows in emerging economies: policies, practices and consequences, pp. 121-169. Chicago, University of Chicago Press, 2007.

European Central Bank, ECB Monthly Bulletin, Economic and Monetary Developments, External Environment in the Euro Area, https://www.ecb.europa.eu/ppdf/mobu/ mb201401en.pdf, 2014.

Friedman, M., The case for flexible exchange rates, [in:] Essays in positive economics, pp. 157-203. University of Chicago Press, 1953.

Ilzetzki, E., Reinhart, C. M., Rogoff, K. S., Exchange Arrangements Entering the $21^{\text {st }}$ Century: Which Anchor Will Hold? NBER Working Paper, no. 23134, 2017.

International Monetary Fund, Annual Report 2017: How to Jump-Start Growth, http://www.imorg/external/pubs/ft/ar/2017/eng/assets/ar17-appII.pdf, 2017.

Ibarra, A. C., Is Latin America Overcoming its Fear of Floating? "Cuadernos de Economía", 44, pp. 183-209, 2017.

Ganapolsky, E. J. J., Optimal Fear of Floating: The Role of Currency Mismatches and Fiscal Constraint, Federal Reserve Bank of Atlanta Working Paper, no. 2003-31, 2003.

García-Solanes, J., Rodríguez López, J., Torres, J. L., Demand Shocks and Trade Balance Dynamics, Universidad Pablo de Olavide, Department of Economics Working Paper, no. 07.10, 2007. 
Ghosh, A., Ostry, J., Qureshi, M., ER Management and Crisis Susceptibility: A Reassessment, "IMF Economic Review", 63 (1), pp. 238-276, 2015.

Ghosh, A. R., Terrones, M., Zettelmeyer, J., Exchange Rate Regimes and External Adjustment: New Answers to an Old Debate, [in:] Wyplosz, C. (ed.), The New International Monetary System: Essays in Honor of Alexander Swoboda. Routledge, 2008.

Ghosh, A. R., Qureshi, M. S., Tsangarides, C. G., Friedman Redux: External Adjustment and Exchange Rate Flexibility, IMF Working Paper, no. 14/146, 2014.

Gregorio, D. J., Resilience in Latin America: Lessons from Macroeconomic Management and Financial Policies, IMF Working Paper, no. 13/259, 2013.

Habermeier, K., Kokenyne, A., Veyrune, R., Anderson, H., Revised System for the Classification of Exchange Rate Arrangements, IMF Working Paper, no. 09/2011, 2009.

Hausmann, R., Panizza, U., Stein, E., Why Do Countries Float the Way They Float? Research Department, Inter-American Development Bank, 1999.

Herrmann, S., Jochem, A., Current account adjustment in EU countries: Does euro-area membership make a difference? Deutsche Bundesbank discussion paper, no. 49, 2013.

Hoffmann, M., Fixed versus flexible exchange rates: A panel VAR analysis, Retrieved from https://web.warwick.ac.uk/res2003/papers/Hoffmann.pdf, 2003.

Hufner, F., Foreign Exchange Intervention as a Monetary Policy Instrument - Evidence for Inflation Targeting Countries. Physica-Verlag Heidelberg, New York 2004.

Janković, M., Impact of financial structure on economic growth: Example of Serbia, Croatia and Slovenia, "Anali Ekonomskog Fakulteta u Subotici”, 55 (42), pp. 147-162, 2020.

Josifidis, K., Allegret, J-P., Gimet, C., Beker Pucar, E., Macroeconomic policy responses to financial crisis in emerging European economies, "Economic Modelling", 36, pp. 577591, 2014.

Kaminsky, G. L., Reinhart, C. M., The twin crises: the causes of banking and balance-ofpayments problems, "The American Economic Review", 89, pp. 473-500, 1999.

Kang, J. S., Shambaugh, J. C., Progress towards external adjustment in the euro area periphery and the Baltics, IMF Working Paper, no. 131, Washington, 2014.

Lane, P. R., Milesi-Ferreti, G. M., Global Imbalances and External Adjustment after the Crisis, IMF Working Paper, no. 14/151, 2014.

Lahiri, A., Vegh, C. A., Living with the Fear of Floating: An Optimal Policy Perspective, [in:] Edwards, E., Frankel, J. (eds.), Preventing Currency Crisis in Emerging Markets. University of Chicago Press, Chicago 2001.

Love, I., Abrigo, M. R. M., Estimation of panel vector autoregression in Stata: A package of programs, http://paneldataconference2015.ceu.hu/Program/Michael-Abrigo.pdf, 2015.

Love, I., Zicchino, L., Financial development and dynamic investment behavior: Evidence from panel VAR, "Quarterly Review of Economics and Finance", 46, pp. 190-210, 2006.

Mishkin, F. S., Can Inflation Targeting Work in Emerging Market Countries, NBER Working Paper, no. 10646, 2004.

Mishkin, F. S., Schmidt-Hebbel, K., Does Inflation targeting make a difference? NBER Working Paper, no. 12876, 2007.

Obstfeld, M., Ostry, J. D., Qureshi, M. S., A Tie That Binds: Revisiting the Trilemma in Emerging Market Economies, IMF Working Paper, no. 17/130, 2017. 
Pesaran, H., A simple panel unit root test in the presence of cross section dependence, Cambridge Working Papers in Economics, no. 0346, Cambridge 2003.

Pietrucha, J., Exchange rate regime and external adjustment in CEE countries, "Journal of Economics and Management”, 20(2), pp. 38-52, 2015.

Rahman, J., Current account developments in new member states of the European Union, IMF Working Paper, no. 92, Washington 2008.

Ranciere, R., Tornell, A., Vamvakidis, A., Currency Mismatch and Systemic Risk in Emerging Europe, G-Mond Working Paper, no. 4, 2010.

Reinhart, C., Goodbye inflation targeting, Hello fear of floating? Latin America after the global financial crisis, MPRA Working Paper, no. 51282, 2013.

Roodman, D., How to do xtabond2: An introduction to difference and system GMM in Stata, "The Stata Journal", 9, pp. 86-139, 2009.

Shelburne, R. C., Current account deficits in European emerging markets, UNECE discussion paper, no. 2008.2, Geneva 2008.

Uzun, A., Financial dollarization, monetary policy stance and institutional structure: the experience of Latin America and Turkey, PhD Thesis, https://etd.lib.metu.edu.tr/upload/ 12606739/index.pdf.

Vamvakidis, A., Convergence in emerging Europe: Sustainability and vulnerabilities, IMF Working Paper, no. 181, Washington 2008.

Received: February 2018, revised: October 2018 